\title{
Analysis of Saturation Risk in Sprinkler Irrigation: Case of Cherfech Irrigation Perimeter in Tunisia
}

\author{
Samir Yacoubi ${ }^{1}$, Adel Slatni ${ }^{1} \&$ Khemaies Zayani ${ }^{2}$ \\ ${ }^{1}$ Institut National de Recherches en Génie Rural, Eaux et Forêts, Tunisia \\ ${ }^{2}$ Institut National Agronomique de Tunisie, Tunisia \\ Correspondence: Samir Yacoubi, Institut National de Recherches en Génie Rural, Eaux et Forêts (INRGREF), BP \\ N¹0, Ariana 2080, Tunisia. E-mail: yacoubi.samir@gmail.com
}

Received: October 23, 2017

Accepted: December 9, 2017

Online Published: January 15, 2018

doi:10.5539/jas.v10n2p130

URL: https://doi.org/10.5539/jas.v10n2p130

\begin{abstract}
This study is targeted to the assessment of the saturation risk in sprinkler irrigation. For this purpose, in situ field trials were carried out to infer the saturated hydraulic conductivity $\left(K_{s}\right)$ and sorptivity $(S)$ using the disc infiltrometer method. Since the measured values of $K_{s}$ are very close to prescribed application rate, caution is required. In a first step, the pressure head at the wetting front $\left(h_{f}\right)$ and the useful porosity $\left(\theta_{s}-\theta_{i}\right)$ are assumed to be constant. Thus, the logarithmic derivation of the sorptivity provides a relation between relative variations of $\mathrm{S}$ and $K_{s}$. The ponding time $\left(T_{s}\right)$ is estimated from Green and Ampt (1911) and Philip (1957b) infiltration equations. The risk of saturation is deemed to be inexistent inasmuch as simulated values of $T_{s}$ are greater than the irrigation times practiced in the zone. In a second step, the values of the pressure head at the wetting front and saturated water content were assumed to be variable with soil texture. Simulations of the ponding time were carried out based on Rawls and al. (1981) data. For the recommended sprinkler spacing in the Cherfech perimeter $(12 \mathrm{~m} \times 12 \mathrm{~m})$, the simulations show a good agreement between $T_{s}$ values generated from Green and Ampt and Philip equations for $K_{s}$ ranging from 1.5 to $6 \mathrm{~mm} / \mathrm{h}$. Moreover, it was established that saturation risk due to a gradual texture variation is virtually inexistent in the conditions prevailing in Cherfech perimeter.
\end{abstract}

Keywords: Saturated hydraulic conductivity, Infiltration rate, ponding time, Saturation hazard, Sprinkler irrigation

\section{Introduction}

The fair distribution of water under sprinkler irrigation is a major concern. Irrigation network should be adapted to the soil texture, crop, available water discharge, water quality and environmental conditions. Results of Playan and Mateos (2006) show that the improvement of the irrigation efficiency depends on the appropriate choice of equipment, pedo-climatic conditions, water availability and socio-economic conditions. The assessment of sprinkler irrigation performance was widely analyzed (Merriam \& Keller, 1978; Heermann et al., 1990; Keller \& Bliesner, 1990; Burt et al., 1997; Pereira, 1999). Tiercelin (1998) and Keller and Bliesner (1990) emphasized that distribution uniformity is a prominent factor in the design and management of sprinkler irrigation systems. The unfair water distribution induces harmful impact on crop yield and environment. Indeed, under irrigation may induce crop yield reduction and soil salinization. Conversely, excess of irrigation may induce crop yield reduction by asphyxia as well as a leaching of fertilizers and pesticides. Solomon (1983) indicated that water stagnation and runoff has a prejudicial impact on soil and crop.

Angulo-Jaramillo et al. (2000), and Trout and Kinkacid (1987) indicated that soil water characterization is of prima facie importance for designing irrigation systems and modeling water movement within the soil. Li and al. (1976) stressed that the determination of the infiltration rate is essential for designing sprinkler irrigation systems. This holds true particularly for high infiltration rates and short irrigation periods. Diamond and Thomas (2003) underlined that the determination of the infiltration rate is fundamental for accurate prediction of runoff. Physically sound formulas show that runoff occurs when rainfall intensity exceeds the saturated hydraulic conductivity. In absence of a shallow water table or an underlying substratum, no runoff is expected when rainfall intensity is very low with respect to the saturated hydraulic conductivity. It is established that the higher the rainfall intensity, the shorter the ponding time. The saturation time may be straightforwardly derived from analytical and empirical infiltration equations (Slack, 1980; Broadbridge \& White, 1987; Kutilek \& Nilsen, 1994; 
Parlange et al., 1999; Smith et al., 2002; Assouline et al., 2007). It is worthy to say that the prerequisite knowledge of the ponding time is necessary to overcome the stagnation hazard. This challenge is all the greater as sprinkler irrigation is commonly practiced on fine soils in Tunisia.

This study is devoted to (i) the estimation of the ponding time under sprinkler irrigation, (ii) the analysis of the saturation risk for gradually variable soil texture taking into account the performance of the irrigation system in Cherfech irrigation perimeter.

\section{Material and Methods}

Field trials were carried out in the experimental station of Cherfech located in the north of Tunisia (latitude $37^{\circ}$ $\mathrm{N}$, longitude $10.5^{\circ} \mathrm{E}$, altitude $328 \mathrm{~m}$ ). The irrigation perimeter of Cherfech covers 2022 ha.

\subsection{Characterization of the Experimental Site}

The climate of the studied zone is semi-arid. It is characterized by a hot summer and moderated and rainy winter. The mean values of annual rainfall and reference evapotranspiration are $443 \mathrm{~mm}$ and $1112 \mathrm{~mm}$, respectively. Table 1 summarizes the values of the soil bulk density $\left(\rho_{\mathrm{d}}\right)$, volumetric soil water contents at the field capacity and at wilting point $\left(\theta_{\mathrm{fc}}\right.$ and $\left.\theta_{\mathrm{wp}}\right)$ as well as granulometric fractions over $1 \mathrm{~m}$ soil depth.

Table 1. Soil water characteristics and granulometry in Cherfech station

\begin{tabular}{lllllll}
\hline Depth $(\mathrm{cm})$ & $\rho_{\mathrm{d}}\left(\mathrm{g} / \mathrm{cm}^{3}\right)$ & $\theta_{\mathrm{fc}}\left(\mathrm{cm}^{3} / \mathrm{cm}^{3}\right)$ & $\theta_{\mathrm{wp}}\left(\mathrm{cm}^{3} / \mathrm{cm}^{3}\right)$ & Clay $(\%)$ & Loam $(\%)$ & Sand $(\%)$ \\
\hline $0-20$ & 1.48 & 0.426 & 0.267 & 28 & 53 & 19 \\
$20-40$ & 1.60 & 0.419 & 0.260 & 26 & 55 & 19 \\
$40-60$ & 1.56 & 0.423 & 0.245 & 22 & 47 & 31 \\
$60-80$ & 1.51 & 0.448 & 0.262 & 21 & 52 & 27 \\
$80-100$ & 1.53 & 0.386 & 0.262 & 17 & 47 & 36 \\
\hline
\end{tabular}

According to the United States Department of Agriculture [USDA] classification, the soil is a fine loam over the depth $0-40 \mathrm{~cm}$ and loamy over the remaining soil depth. The mean electrical conductivity of the water irrigation, supplied by Medjerda Channel, is equal to $2.6 \mathrm{dS} / \mathrm{m}$.

\subsection{Determination of the Soil Infiltrability}

The infiltration law was established using the infiltrometer disc method (Peroux \& White, 1988). Contrariwise to the double ring method of Muntz (Maheshwari, 1996), the disc infiltrometer method has the merit to provide hydraulic conductivity at the saturation and also hydraulic conductivities for very low soil water pressure heads (Coquet et al., 2000). The estimation of $\mathrm{K}_{\mathrm{s}}$ by the disc infiltrometer is based on the Wooding (1968) equation:

$$
q_{\infty}\left(h_{0}\right)=K\left(h_{0}\right)+\frac{4 \Phi\left(h_{0}\right)}{\pi r}
$$

where, $q_{\infty}, h_{0}, K, \Phi$ and $r$ refer to the infiltration density rate $\left[\mathrm{LT}^{-1}\right]$, imposed potential at the soil surface [L], soil water conductivity $\left[\mathrm{LT}^{-1}\right]$, Kirchhoff potential $\left[\mathrm{L}^{2} \mathrm{~T}^{-1}\right]$ and the radius of the infiltrometer disc $[\mathrm{L}]$.

Equation (1) was derived from steady state regime under axisymmetric flow from a surface point source. Assuming that soil water conductivity varies exponentially with soil water pressure head (Gardner, 1958, $K(h)=$ $\left.K_{s} e^{\alpha h}\right)$, the infiltration density rate may be written as:

$$
q_{\infty}\left(h_{0}\right)=K\left(h_{0}\right)\left(1+\frac{4}{\pi r \alpha}\right)
$$

The approach of multi-potential disc infiltrometer developed by Reynolds and Elrick (1991) and by Ankeny et al. (1991) allow the inference of the parameters of $K(h)$ law from the knowledge of two pairs of discharge-soil water pressure head.

$$
\left\{\begin{array}{l}
Q_{\infty}\left(h_{1}\right)=\pi r^{2} K_{s} e^{\alpha} h_{1}\left(1+\frac{4}{\pi r \alpha}\right) \\
Q_{\infty}\left(h_{2}\right)=\pi r^{2} K_{s} e^{\alpha} h_{2}\left(1+\frac{4}{\pi r \alpha}\right)
\end{array}\right.
$$

The sorptive number $\alpha\left(\mathrm{L}^{-1}\right)$ is straightforwardly derived from solving the above equation system.

$$
\alpha=\frac{\ln \left[Q_{\infty}\left(h_{2}\right)\right]-\ln \left[Q_{\infty}\left(h_{1}\right)\right]}{h_{2}-h_{1}}
$$


The knowledge of $\alpha$ allows the inference of $K_{s}$ from one equation of equation sytem (3). At the opposite, the mono-potential method developed by White and Sully (1987) has the advantage to be applicable for only one pair of emitter discharge-soil water pressure head:

$$
\Phi\left(h_{0}\right)=\frac{b S^{2}}{\theta_{s}-\theta_{i}}
$$

where, $S, \theta_{s}$ and $\theta_{i}$ refer to the soil sorptivity $\left[\mathrm{L} / \mathrm{T}^{1 / 2}\right]$, saturated and initial soil water contents respectively.

The parameter " $b$ " depends on the shape of $K(h)$ and $\theta(h)$ curves. According to Warrick and Broadbridge (1992), the value of $b$ ranges from 0.5 to 0.8 and may be assigned to 0.55 . Combining Equations (2) and (5) leads to:

$$
q_{\infty}\left(h_{0}\right)=K\left(h_{0}\right)+\frac{4 b s^{2}}{\pi r\left(\theta_{s}-\theta_{i}\right)}
$$

The soil sorptivity depends on the hydraulic soil diffusivity, initial and saturated water contents. It may be derived from the infiltration law at short times. Indeed, Philip (1957a) established the following infiltration law when water movement is only governed by capillary forces:

$$
I(t)=S \sqrt{t}
$$

where, $I$ and $t$ refer to the cumulative infiltration and elapsed time, respectively. The saturated hydraulic conductivity may be inferred from infiltration law of Philip (1957b):

$$
I(t)=S \sqrt{t}+A t
$$

where, the term $A$ accounts for gravitational effect. It is tantamount to the saturation hydraulic conductivity.

\subsection{Experimental Layout}

Three infiltration trials were carried out on a bare soil at the Cherfech station. The method of disc infiltrometer was used with $20 \mathrm{~cm}$ as disc diameter. Two trials were performed with the mono-potential method at soil suctions equal to -5 and $-2 \mathrm{~cm}$. The third trial was carried out using the multi-potential method with a pair of soil suction $(-16 \mathrm{~cm},-6 \mathrm{~cm})$. For all the trials, a thin sand layer was placed at the interface between the disc and the soil surface to mitigate the effect of asperities and ascertain a good contact between the soil and the membrane. Initial and final water contents were measured by sampling soil beneath and at the vicinity of the disc. Figure 1 displays the experimental device used for measuring the saturated hydraulic conductivity by the disc infiltrometer method.
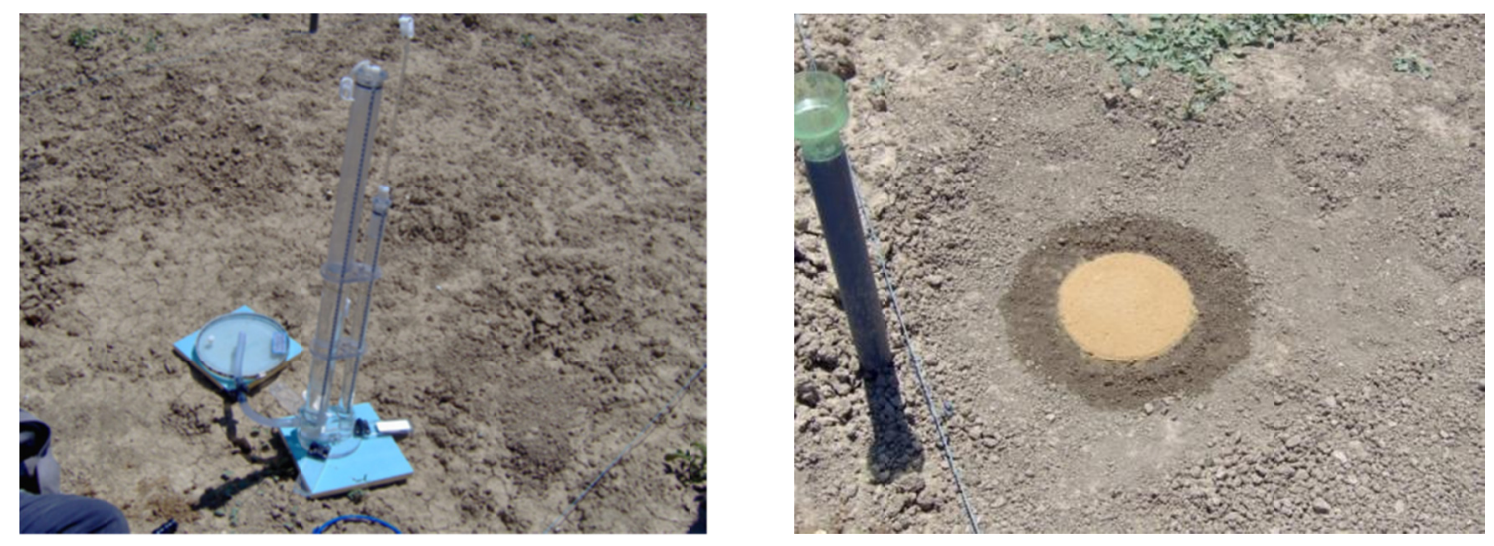

Figure 1. In situ measurement of the saturated hydraulic conductivity using the disc infiltrometer method at Cherfech station

\subsection{Estimation of the Ponding Time}

In this study, two well-known physically sound equations were used for modelling soil water infiltration: Green and Ampt (1911) and Philip (1957b). Following Kutilek and Nielsen (1994), the ponding time may be written as following for constant rainfall intensity:

\subsubsection{Green and Ampt Equation}

$$
T_{S}=\frac{S^{2}}{2 K_{S}\left(\mathrm{i}-K_{S}\right)} \ln \left(\frac{i}{i-K_{S}}\right)
$$


Where, $i$ refers to the rainfall intensity $\left[\mathrm{LT}^{-1}\right]$. It is worth to remind that Green and Ampt equation holds true when soil hydraulic diffusivity obeys a Dirac function.

\subsubsection{Philip Equation}

$$
T_{s}=\frac{S^{2}\left(2 i-K_{s}\right)}{4 i\left(i-K_{s}\right)^{2}}
$$

By comparing Green and Ampt (1911), and Philip (1957b) equations at short times, one can deduce:

$$
\mathrm{S}=\sqrt{2 K_{s}\left(h_{0}-h_{f}\right)\left(\theta_{s}-\theta_{i}\right)}
$$

where, $h_{0}$ and $h_{f}$ refer to the water depth at the soil surface and the soil suction at the wetting front, respectively. It should be highlighted that $h_{f}$ is assumed to be soil depth independent in the theory of Green and Ampt (1911).

Considering the dimensionless variables:

$$
\left\{\begin{array}{c}
T^{*}=\frac{2\left(i-K_{S}\right) K_{S} T_{S}}{S^{2}} \\
i^{*}=\frac{i}{K_{s}}
\end{array}\right.
$$

Equations (9) and (10) may be written as following:

Green and Ampt:

$$
T^{*}=\ln \left(\frac{i^{*}}{i^{*}-1}\right)
$$

Philip:

$$
T^{*}=\frac{2 i^{*}-1}{2 i^{*}\left(i^{*}-1\right)}
$$

In the same site, Yacoubi et al. (2012) have shown that sprinkler spacing of $12 \mathrm{~m} \times 12 \mathrm{~m}$ and a pressure head of 3 bars at the nozzle provide the better distribution uniformity $(76.8 \% \leq \mathrm{CU} \leq 86.1 \%)$ for wind speeds less than 4 $\mathrm{m} / \mathrm{s}$. Under these circumstances, the recommended application rate is equal to $9 \mathrm{~mm} / \mathrm{h}$.

\section{Results and Discussion}

\subsection{Infiltration and Hydraulic Conductivity}

Recorded infiltration data under a soil suction of $-2 \mathrm{~cm}$ were used to establish the infiltration equation. Figure 2 illustrates the relationship between the cumulative infiltration depth and the elapsed time.

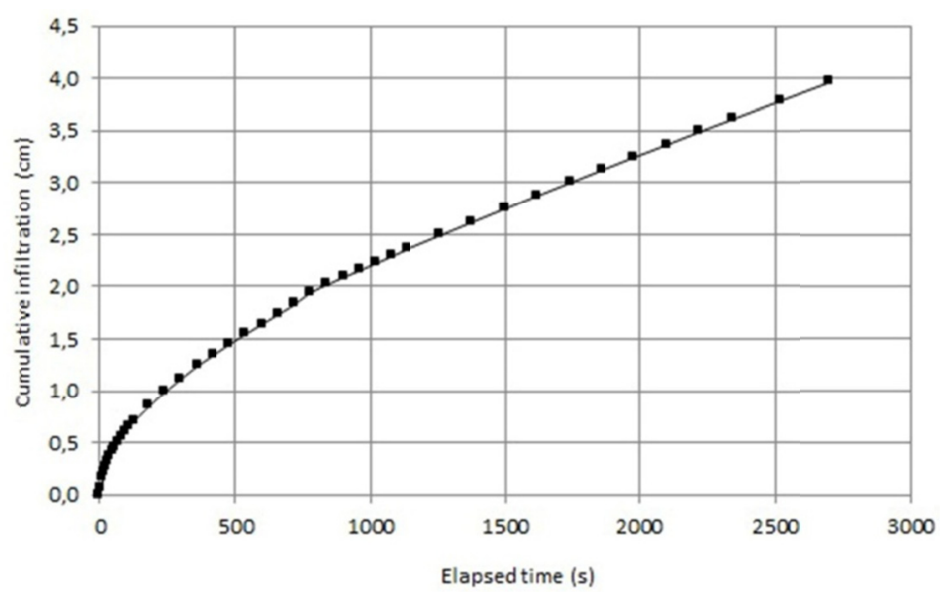

Figure 2. Cumulative infiltration versus elapsed time under $-2 \mathrm{~cm}$ soil suction (mono-potential trial)

Fitting the scattered data according to Philip (1957b) equation leads to:

$$
I(t)=0.059 \sqrt{t}+0.000314 t \quad\left(\mathrm{R}^{2}=0.99\right)
$$

where, $I$ and $t$ are expressed in $\mathrm{cm}$ and $\mathrm{s}$, respectively. 
The high value of the correlation coefficient $\mathrm{R}$ indicate a very good agreement between fitted and observed results. The value of $A$ provides a saturated hydraulic conductivity equal to $11.3 \mathrm{~mm} / \mathrm{h}$. Subsequently, application rates should be fixed less than this threshold to prevent ponding and runoff. Table 2 summarizes the values of $S$ and $K_{s}$ measured by the mono-potential (2a) and multi-potential methods (2b).

Table 2. Soil water characteristics using the disc infiltrometer

2a. mono-potential method

\begin{tabular}{llllll}
\hline$h_{0}(\mathrm{~cm})$ & $\theta_{i}\left(\mathrm{~cm}^{3} / \mathrm{cm}^{3}\right)$ & $\theta_{s}\left(\mathrm{~cm}^{3} / \mathrm{cm}^{3}\right)$ & $S\left(\mathrm{~cm} / \mathrm{s}^{1 / 2}\right)$ & $K\left(h_{0}\right)(\mathrm{mm} / \mathrm{h})$ & $K_{s}(\mathrm{~mm} / \mathrm{h})$ \\
\hline-5 & 0.074 & 0.497 & 0.0712 & 5.8 & 10.7 \\
-2 & 0.157 & 0.500 & 0.0615 & 8.2 & 11.3 \\
\hline
\end{tabular}

2b. multi-potential method

\begin{tabular}{llll}
\hline$h_{0}(\mathrm{~cm})$ & $Q_{\infty}\left(h_{0}\right)\left(\mathrm{cm}^{3} / \mathrm{h}\right)$ & $\alpha\left(\mathrm{cm}^{-1}\right)$ & $K_{s}(\mathrm{~mm} / \mathrm{h})$ \\
\hline-16 & 70 & 0.118 & 7.1 \\
-6 & 227 & & \\
\hline
\end{tabular}

It should be emphasized that the two trials were performed in different points. According to Nielsen et al. (1973) and Vauclin et al. (1994), the saturated hydraulic conductivity is widely affected by the spatial soil variability. Therefore, we can assume that $K_{s}$ values presented in tables (2a) and (2b) are virtually of the same order of magnitude. These values are in a good agreement with $K_{s}$ values reported by Hillel (1974) for loamy textured soils $\left(\mathrm{K}_{\mathrm{s}}\right.$ ranging from 5 to $\left.10 \mathrm{~mm} / \mathrm{h}\right)$.

\subsection{Saturation Risk Analysis for on Sprinkler Spacing of $12 \mathrm{~m} \times 12 \mathrm{~m}$}

For a given pressure head at the sprinkler nozzle, the discharge is constant. Therefore, the decrease of the sprinkler spacing induce an increase of the application rate. Consequently, caution is required to avoid saturation and runoff hazards when sprinklers are close to each other. The narrow gap between saturated hydraulic conductivity $(11.3 \mathrm{~mm} / \mathrm{h})$ and suitable application rate $(9 \mathrm{~mm} / \mathrm{h})$ incited us to investigate the risk of soil saturation. Assuming that $\left(h_{0}-h_{f}\right)\left(\theta_{s}-\theta_{i}\right)$ is constant, the logarithmic derivation of Equation (11) leads to the following expression:

$$
\frac{\Delta S}{S}=\frac{\Delta K_{S}}{K_{S}}
$$

It should be stressed that Green and Ampt (1911) and Philip (1957b) equations assume a uniform soil texture and constant initial water content all over the soil depth. It is obvious that perfect uniformity is an idyllic schematization of the reality. This is why we investigated the impact of an eventual texture change on the ponding time. Hereinafter, we assumed that soil texture varies from clay loam to silt loam. For these soil types, $K_{s}$ varies from 1.5 to $7.6 \mathrm{~mm} / \mathrm{h}$ according to the National Engineering Handbook (1991). The sorptivity values were calculated using an incremental approach based on Equation (16). The derived ponding times were determined for a constant application rate of $9 \mathrm{~mm} / \mathrm{h}$.

Figure 3 displays the evolution of the ponding time with respect to $K_{s}$ for the two aforementioned equations. 


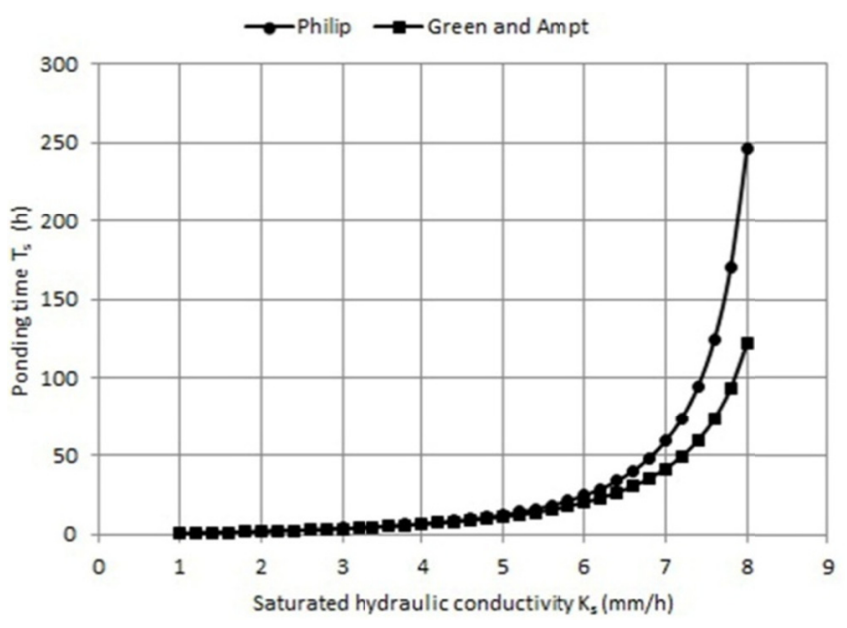

Figure 3. Ponding time versus $\mathrm{K}_{\mathrm{s}}$ for the two infiltration equations in the Cherfech station

Figure 3 shows that the ponding times calculated by the two methods are virtually identical for $K_{s}$ ranging from 1.5 to $6 \mathrm{~mm} / \mathrm{h}$. Regarding the practical irrigation times in the region (4-6 hours), Figure 3 shows that the saturation risk is quasi inexistent for $K_{s}$ ranging from 4.5 to $7.6 \mathrm{~mm} / \mathrm{h}$. Inasmuch as the infiltration rate should be higher than or equal to $3 \mathrm{~mm} / \mathrm{h}$ for sprinkler irrigation to be operated (Keller \& Bliesner, 1990), simulation results show that ponding time is approximately equal to 4 hour.

The comparison between dimensionless ponding time Equations (13) and (14) shows a small discrepancy between Green and Ampt (1911) and Philip (1957b) formulations. For high dimensionless infiltration rates $\left(i^{*}\right)$, Figure 4 shows a very good agreement between the two equation.

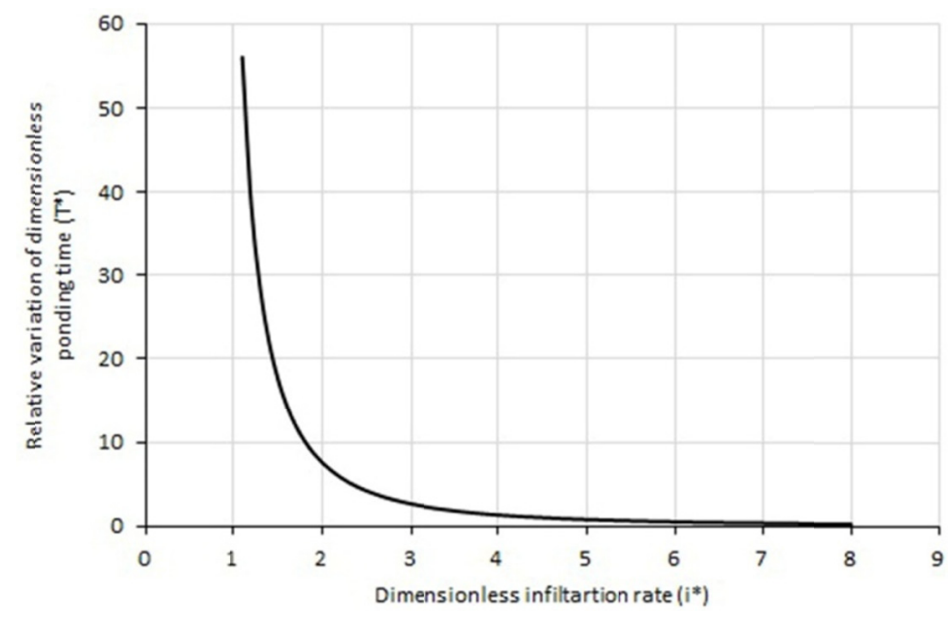

Figure 4. Relative variation of dimensionless ponding time versus dimensionless infiltration rate

In the previous simulations, the pressure head at the wetting front $\left(h_{f}\right)$ was assumed to be soil depth independent. Nevertheless, results of Rawls et al. (1981) show that $h_{f}$ and effective porosity $\left(\theta_{s}-\theta_{i}\right)$ vary according to the soil texture. In what follows, we perform simulations of the ponding time on the basis Rawls et al. (1981) data for three soil textures: Sandy clay loam, loam and silt loam. 
Table 3. Ponding time for three soil texture based on Rawls et al. (1981) data

\begin{tabular}{lllllll}
\hline \multirow{2}{*}{ Soil texture } & \multicolumn{3}{c}{ Data of Rawls et al. (1981) } & \multirow{2}{*}{$T_{s}$} \\
\cline { 2 - 4 } \cline { 6 - 7 } & $K_{s}$ & $\theta_{s}-\theta_{i}$ & $h_{f}-h_{0}$ & & Phil 11) & Green and Ampt \\
\hline Sandy clay loam & 1.5 & 0.330 & 218.5 & 14.7 & 1.8 & 1.8 \\
loam & 3.4 & 0.434 & 88.9 & 16.2 & 3.3 & 3.4 \\
Silt loam & 6.5 & 0.486 & 166.8 & 32.5 & 41.5 & 53.9 \\
\hline
\end{tabular}

Values of $\left(h_{f}-h_{0}\right),\left(\theta_{s}-\theta_{i}\right), K_{s}, S$ and $T_{s}$ are expressed in $\mathrm{mm}, \mathrm{cm}^{3} / \mathrm{cm}^{3}, \mathrm{~mm} / \mathrm{h}, \mathrm{mm} / \mathrm{h}^{1 / 2}$ and h, respectively. Table 3 indicated that ponding times are of the same magnitude than those depicted in Figure 3. Definitively, Figure 3 and Table 3 show that the risk of soil saturation generated by a gradual soil texture variation is virtually inexistent for the practical irrigation times in the study region. Referring to the pedology map of the zone, one can claim that it is unlikely that saturated soil hydraulic conductivity varies from 3 to $11.3 \mathrm{~mm} / \mathrm{h}$.

\section{Conclusion}

Field trials showed that optimal application rate is equal to $9 \mathrm{~mm} / \mathrm{h}$ for a sprinkler spacing of $12 \mathrm{~m} \times 12 \mathrm{~m}$. This application rate is so close to the saturated hydraulic conductivity $(11.3 \mathrm{~mm} / \mathrm{h})$. To assess the soil saturation hazard due to the spatial soil variability, we compared the calculated ponding times to the irrigation times operated in the study region. It was established that Green and Ampt (1911) and Philip (1957b) methods produce similar results for $K_{s}$ ranging within 1.5 to $6 \mathrm{~mm} / \mathrm{h}$. The estimated ponding times are greater than operated irrigation times in the region. Therefore, one can conclude that the saturation risk is virtually inexistent in the study area. Consequently, farmers can use the prescribed application rate without saturation hazard. This application rate is the best compromise between energy cost and water distribution uniformity.

\section{Acknowledgements}

The authors are thankful to the National Research Institute for Rural Engineering, Water and Forestry (INRGREF) for the valuable support of this research.

\section{References}

Angulo-Jaramillo, R., Gaudet, J. P., Thony, J. L., \& Vauclin, M. (1996). Measurement of hydraulic properties and mobile water content of a field soil. Soil Science Society of America Journal, 60, 710-715. https://doi.org/ 10.2136/sssaj1996.03615995006000030004x

Ankeny, M. D., Ahmed, M., Kaspar, T. C., \& Horton, R. (1991). Simple field method for determining unsaturated hydraulic conductivity. Soil Science Society of America Journal, 5, 467-470. https://doi.org/ $10.2136 /$ sssaj $1991.03615995005500020028 \mathrm{x}$

Assouline, S., Selker, J. S., \& Parlange, J.-Y. (2007). A simple accurate method to predict time of ponding under variable intensity rainfall. Water Resour. Res., 43, W03426. https://doi.org/10.1029/2006WR005138

Broadbridge, P., \& White, I. (1987). Time to ponding: Comparison of analytic, quasi-analytic, and approximate predictions. Water Resour. Res., 23, 2302-2310. https://doi.org/10.1029/WR023i012p02302

Burt, C. M., Clemmens, A. J., Strelkoff, T. S., Solomon, K. H., Bliesner, R. D., Hardy, L. A., ... Eisenhauer, D. E. (1997). Irrigation performance measures: Efficiency and uniformity. Journal of Irrigation and Drainage Engineering, 123(6), 423-442. https://doi.org/10.1061/(ASCE)0733-9437(1997)123:6(423)

Coquet, Y., Boucher, A., Labat, C., Vachier, P., \& Roger-Estrade, J. (2000). Caractérisation hydrodynamique des sols à l'aide de l'infiltromètre à disques: Aspects théoriques et pratiques. Etude et Gestion des Sols, 7(1), 7-24. Retrieved from http://www.afes.fr/wp-content/uploads/2017/10/EGS_7_1_coquet.pdf

Diamond, J., \& Thomas, S. (2003). Infiltration rate assessment of some major soils. Irish Geography, 36(1), 32-46. https://doi.org/10.1080/00750770309555810

Gardner, W. F. (1958). Some steady-state solutions of the unsaturated moisture flow equation with application to evaporation from a water table. Soil Science, 85, 228-232. https://doi.org/10.1097/00010694-19580400000006

Green, W. H., \& Ampt, G. A. (1911). Studies on soil physics. Part I: The flow of air and water through soils. J. Ag. Sci., 4(1), 1-24. https://doi.org/10.1017/S0021859600001441 
Heermann, D. F., Wallender, W. W., \& Bos, G. M. (1990). Irrigation efficiency and uniformity. In G. J. Hoffman, T. A. Howell, \& K. H. Solomon (Eds.), Management of Farm Irrigation Systems (pp. 125-149). ASAE, St. Joseph, MI.

Hillel, D. (1974). L'eau et le sol: Principes et processus physiques (p. 288). Louvain Vander Eds., Paris.

Keller, J., \& Bliesner, R. D. (1990). Sprinkler and trickle irrigation. Van Nostrand Reinhold, New York, USA. https://doi.org/10.1007/978-1-4757-1425-8

Kutilek, M., \& Nilsen, D. R. (1994). Soil Hydrology (p. 370). Catena, Reiskirchen, Germany.

Li, R. M., Stevens, M. A., \& Simons, D. B. (1976). Solutions to Green-Ampt infiltration equation. J. Irrig. Drain. Div., 102(2), 239-248.

Maheshwari, B. L. (1996). Development of an automated double ring infiltrometer. Aust. J. Soil. Res., 34(5), 709-714. https://doi.org/10.1071/SR9960709

Merriam, J. L., \& Keller, J. (1978). Farm irrigation system evaluation: A guide for management. Utah State University, Logan, Utah.

National Engineering Handbook. (1991). Sprinkler irrigation (Section 15, Chapter 11). United States Department of Agriculture, Soil Conservation Service.

Nielsen, D. R., Biggar, J. W., \& Erh, K. T. (1973). Spatial variability of field-measured soil-water properties. Hilgardia, 42(7), 215-259. https://doi.org/10.3733/hilg.v42n07p215

Parlange, J.-Y., Hogarth, W. L., Barry, D. A., Parlange, M. B., Haverkamp, R., Ross, P. J., ... Katul, G. (1999). Analytical approximation to the solutions of Richards' equation with applications to infiltration, ponding, and time compression approximation. Advances in Water Resources, 23, 189-194. https://doi.org/10.1016/ S0309-1708(99)00022-6

Pereira, L. S. (1999). Higher performance through combined improvements in irrigation methods and scheduling: A discussion. Agric. Water Manag., 40, 153-169. https://doi.org/10.1016/S0378-3774(98)00118-8

Peroux, K. M., \& White, I. (1988). Design for disc permeameters. Soil Science Society of America Journal, 52, 1205-1215. https://doi.org/10.2136/sssaj1988.03615995005200050001x

Philip, J. R. (1957a). Numerical solution of equations of the diffusion type with diffusivity concentration-dependant. Australian Journal of Physics, 10(1), 29-42. https://doi.org/10.1071/PH570029

Philip, J. R. (1957b). The theory of infiltration: 4. Sorptivity and algebraic infiltration equations. Soil Sci., 84(3), 257-264. https://doi.org/10.1097/00010694-195709000-00010

Playán, E., \& Mateos, L. (2006). Modernization and optimization of irrigation systems to increase water productivity. Agricultural Water Management, 80, 100-116. https://doi.org/10.1016/j.agwat.2005.07.007

Rawls, W. J., Brakensiek, D. L., \& Saxton, K. E. (1981). Soil water characteristics. ASAE Paper No. 81-2510.

Reynolds, W. D., \& Elrick, D. E. (1991). Determination of hydraulic conductivity using a tension infiltrometer. Soil Sci. Soc. of Amer. Jour., 55, 633-639. https://doi.org/10.2136/sssaj1991.03615995005500030001x

Slack, D. (1980). Modeling infiltration under moving sprinkler irrigation system. Transactions of the ASAE, 23(3), 0596-0600. https://doi.org/10.13031/2013.34631

Smith, R. E., Smettem, K. R. J., Broadbridge, P., \& Woolhieser, D. A. (2002). Infiltration Theory for Hydrologic Applications (Vol. 15). AGU, Washington DC. https://doi.org/10.1029/WM015

Solomon, K. H. (1983). Irrigation uniformity and yield theory (PhD thesis, Department of Agricultural and Irrigation Engineering, Utah State University, Logan, Utah).

Tiercelin, J. R. (1998). Traité d'irrigation (p. 1011). Lavoisier: Tec et Doc.

Trout, T. J., \& Kincaid, D. C. (1987). Infiltration research needs for irrigated agriculture. ASAE Paper No. 872538. St. Joseph, Mich.: ASAE.

Vauclin, M., Elrick, D. E., Thony, J. L., Vachaud, G., Revol, Ph., \& Ruelle, P. (1994). Hydraulic conductivity measurements of the spatial variability of a loamy soil. Soil Technology, 7, 181-195. https://doi.org/10.1016/ 0933-3630(94)90020-5

Warrick, A. W., \& Broadbridge, P. (1992). Sorptivity and macroscopic capillary length relationships. Water Resour. Res., 28, 427-431. https://doi.org/10.1029/91WR02599 
White, I., \& Sully, M. J. (1987). Macroscopic and microscopic capillary length and time scales from field infiltration. Water Resour. Res., 23, 1514-1522. https://doi.org/10.1029/WR023i008p01514

Wooding, R. A. (1968). Steady Infiltration from a Shallow Circular Pond equation. Water Resour. Res., 4, 1259-1273. https://doi.org/10.1029/WR004i006p01259

Yacoubi, S., Zayani, K., Slatni, A., \& Playan, E. (2012). Assessing sprinkler irrigation performance using field evaluations at the Medjerda lower valley of Tunisia. Engineering, 4(10), 682-691. https://doi.org/10.4236/ eng.2012.410087

\section{Copyrights}

Copyright for this article is retained by the author(s), with first publication rights granted to the journal.

This is an open-access article distributed under the terms and conditions of the Creative Commons Attribution license (http://creativecommons.org/licenses/by/4.0/). 